\title{
Invasion of the alien gecko Hemidactylus mabouia (Moureau de Jonnès, 1818) in a natural habitat at Praia do Sul Biological Reserve, Ilha Grande, RJ, Brazil
}

\author{
Telles, FBS. ${ }^{a}{ }^{*}$, Militão, CM. , Bergallo, $H G{ }^{a}{ }^{a}$ and Rocha, CFD. ${ }^{a}$
}

${ }^{a}$ Laboratório de Ecologia de Vertebrados, Programa de Pós-graduação em Ecologia e Evolução, Departamento de Ecologia, Universidade do Estado do Rio de Janeiro - UERJ, Avenida São Francisco Xavier, 524, PHLC, Sala 224, Maracanã,

CEP 20550-013, Rio de Janeiro, RJ, Brazil

*e-mail: fbottona@yahoo.com.br

Received: September 16, 2014 - Accepted: January 29, 2015 - Distributed: August 31, 2015

The gekkonid lizard Hemidactylus mabouia (Moreau De Jonnès 1818) is an exotic species widely distributed in South America, Central America and the Caribbean, which nowadays is rapidly colonizing and spreading in the southern portion of North America (Butterfield et al., 1993). The colonization of the New World occurred naturally from African lineages, at least twice, and had devastated consequences for other geckos (Carranza and Arnold, 2006) and for other native species (Rödder et al., 2008). A recent study compiling 70 years of published data from natural environments indicated that this exotic species has already invaded many natural environments in the Brazilian territory (Rocha et al., 2011a, b), with a steadily increase of records in the last three decades (Rocha et al., 2014). The occurrence of $H$. mabouia in natural habitats of 36 localities from 13 Brazilian states changed the status of the species from a merely exotic condition to an exotic invasive species in Brazil (Rocha et al., 2011a). An ecological invasion occurs when a non-indigenous species (exotic) is introduced in a natural environment and can defeat ecological resistance, get established, proliferate and disperse, maintaining a viable population through time (Rejmánek, 1999). At Ilha Grande (one of the largest insular remains of the Atlantic Rainforest located in southwestern Rio de Janeiro state), a recent study analyzed the occurrence of $H$. mabouia in natural and anthropic/perianthropic habitats along $71 \mathrm{~km}$ of trails at the island and no individual was recorded in natural environments but only in anthropic/perianthropic habitats with the gecko not being considered an invasive species on the island, but still remaining locally as an exotic species (Rocha and Bergallo, 2011). In a recent survey conducted at Reserva Biológica Estadual da Praia do Sul (Praia do Sul Biological Reserve), a protected area in Ilha Grande State Park, Angra dos Reis, RJ, Brazil we recorded 17 individuals (and two eggs) of Hemidactylus mabouia living in natural environments (Appendix 1). The record of gravid females, eggs and young individuals indicated that this population is effectively reproducing locally. Voucher specimens were deposited at Vertebrate Collection, Museu Nacional, Rio de Janeiro (MNRJ). A study conducted at Praia do Sul between 2008 and 2011 (Winck, 2012), using same survey methods (time-constrained active search) and similar efforts in the restinga zone (halophilic-psammophilous) where some individuals were found (see Apendix 1), failed to record any individual of $H$. mabouia, suggesting that the invasion in the restinga by this gecko should be very recent. Rocha et al. (2011a) found that most environments where H. mabouia successfully invaded (30 out of 32 cases or 94\%) were open habitats (such as restingas, coastal rocky hills, sand dunes, Cerrados and rocky islands) with cases of invasion in forested environments comparatively rare probably due to more restricted thermal characteristics of those environments compared with more open habitats. In fact, just one of our records comes from forested environments. Data presented here are the first records of $H$. mabouia as invasive at Ilha Grande, corroborating the view that the invasion by this species may be favored in open habitats.

\section{Acknowledgements}

The Coordenação de Aperfeiçoamento de Pessoal de Nível Superior (CAPES) provided a Doctoral scholarship to FBST. Research grants were provided to CFDR (304791/2010-5 and 472287/2012-5) and to HGB (307715/2009-4) from CNPq and through "Cientistas do Nosso Estado" Program from FAPERJ to CFDR (E-26/102.765.2012) and to HGB (E-26.103.016.2011).

\section{References}

BUTTERFIELD, BP., HAUGE, B. and MESHAKA, WE., 1993. The occurrence of Hemidactylus mabouia on the United States mainland. Herpetological Review, vol. 24, no. 3, p. 111-112.

CARRANZA, S. and ARNOLD, EN., 2006. Systematics, biogeography, and evolution of Hemidactylus geckos (Reptilia: Gekkonidae) elucidated using mitochondrial DNA sequences. Molecular Phylogenetics and Evolution, vol. 38, no. 2, p. 531-545. http://dx.doi.org/10.1016/j.ympev.2005.07.012. PMid:16154768.

REJMÁNEK, M., 1999. Invasive plants and invasible ecosystems. In SANDLUND, O.T., SCHEI, P.J. and VIKEN, A. (Eds.). Invasive species and biodiversity management. Boston: Kluwer Academic Publishers. p. 79-102. 
ROCHA, CF. and BERGALLO, HG., 2011. Occurrence and distribution of the exotic lizard Hemidactylus mabouia Moreau de Jonnès, 1818 in Ilha Grande, RJ, Brazil. Revista Brasileira de Biologia $=$ Brazilian Journal of Biology, vol. 71, no. 2, p. 447-450. PMid:21755162.

ROCHA, CFD., ANJOS, LA. and BERGALLO, HG., 2011a. Conquering Brazil: the invasion by the exotic gekkonid lizard Hemidactylus mabouia (Squamata) in Brazilian natural environments. Zoologia, vol. 28, no. 6, p. 711-723. http://dx.doi.org/10.1590/ S1984-46702011000600007.

ROCHA, CFD., BERGALlO, HG. and MAZZONI, R., 2011b. Invasive vertebrates in Brazil. In PIMENTEL, D. (Ed.). Biological invasions: economic and environmental costs of alien plant, animal and microbe species. 2nd ed. New York: Taylor \& Francis. p. 53-103.
ROCHA, CFD., VRCIBRADIC, D., KIEFER, MC., MENEZES, VA., FONTES, AF., HATANO, FH., GALDINO, CA., BERGALLO, HG. and VAN SLUYS, M., 2014. Species composition, richness and nestedness of lizard assemblages from Restinga habitats along the brazilian coast. Revista Brasileira de Biologia $=$ Brazilian Journal of Biology, vol. 74, no. 2, p. 349-354. PMid:25166319.

RÖDDER, D., SOLÉ, M. and BÖHME, W., 2008. Predicting the potential distributions of two alien invasive Housegeckos (Gekkonidae: Hemidactylus frenatus, Hemidactylus mabouia). North-Western Journal of Zoology, vol. 4, no. 2, p. 236-246.

WINCK, GR., 2012. Comunidades de lagartos nos remanescentes de restinga do Estado do Rio de Janeiro: riqueza, diversidade e onde estão as espécies endêmicas e ameaçadas de extinção. Programa de Pós-Graduação em Ecologia e Evolução, Instituto de Biologia, Universidade do Estado do Rio de Janeiro. 183 p. Tese de doutorado. 
Appendix 1. Records of individuals and eggs of Hemidactylus mabouia registered in the Reserva Biológica Estadual da Praia do Sul, Ilha Grande, Rio de Janeiro, including date, time, coordinates, habitat, snout-vent length (SVL, in mm) and life stage of individuals and voucher number for some individuals sampled.

[On 16/09/12 at 18:34 in evergreen forest, gravid female, 64,6mm SVL, 23 ${ }^{\circ} 10^{\prime} 58.46^{\prime \prime} \mathrm{S} / 44^{\circ} 18^{\prime} 55.45^{\prime \prime} \mathrm{W}$, MNRJ 24658) On 18/09/12 at 22:23, adult, in rocky hill, $23^{\circ} 10^{\prime} 58.73^{\prime \prime} \mathrm{S} / 44^{\circ} 18^{\prime} 51.43^{\prime \prime} \mathrm{W}$ ) On 13/10/12 at 21:45 adult, $58,9 \mathrm{~mm}$ SVL in rocky hill, $\left.23^{\circ} 10^{\prime} 50.61^{\prime \prime} \mathrm{S} / 44^{\circ} 18^{\prime} 41.43^{\prime \prime} \mathrm{W}\right)$ On 11/10/13, at 17:50 in restinga area, adult male $65,6 \mathrm{~mm}$

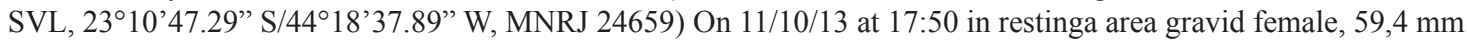

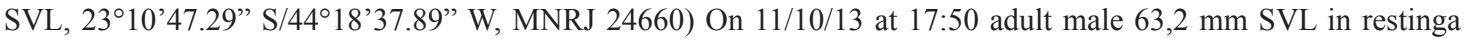

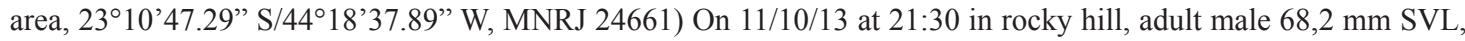
$\left.23^{\circ} 10^{\prime} 50.61^{\prime \prime} \mathrm{S} / 44^{\circ} 18^{\prime} 41.43^{\prime \prime} \mathrm{W}, \mathrm{MNRJ} 24662\right)$ On 11/10/13 at 21:33 in rocky hill, juvenile $40.8 \mathrm{~mm} \mathrm{SVL}, 23^{\circ} 10^{\prime} 52.89^{\prime \prime}$ $\mathrm{S} / 44^{\circ} 18^{\prime} 43.54^{\prime}$ 'W, MNRJ 24663) On 11/10/13 at 21:38, adult in rocky hill, $\left.23^{\circ} 10^{\prime} 52.14^{\prime \prime} \mathrm{S} / 44^{\circ} 18^{\prime} 41^{\prime} 82^{\prime \prime} \mathrm{W}\right) \mathrm{On}$ $12 / 10 / 13$ at 16:00 adult, in rocky hill, $\left.23^{\circ} 10^{\prime} 50.61^{\prime \prime} \mathrm{S} / 44^{\circ} 18^{\prime} 41.43^{\prime \prime} \mathrm{W}\right)$ On 12/10/13 at 19:15, adult in rocky hill, $\left.23^{\circ} 10^{\prime} 59.62^{\prime \prime} \mathrm{S} / 44^{\circ} 18{ }^{\prime} 53.59^{\prime \prime} \mathrm{W}\right)$ On $15 / 10 / 13$ at $14: 37$, two eggs found in restinga, $23^{\circ} 10^{\prime} 46.69^{\prime}$ S $\left./ 44^{\circ} 18^{\prime} 34.99^{\prime \prime} \mathrm{W}\right)$ On $02 / 04 / 14$ at $21: 30$ juvenile in rocky hill, $23^{\circ} 10^{\prime} 52.09^{\prime \prime} \mathrm{S} / 44^{\circ} 18^{\prime} 43.10^{\prime \prime} \mathrm{W}$ ) On $02 / 04 / 14$ at $21: 31$ juvenile in rocky hill, $\left.23^{\circ} 10^{\prime} 52.46^{\prime \prime} \mathrm{S} / 44^{\circ} 18^{\prime} 43.50^{\prime \prime} \mathrm{W}\right)$ On 04/04/14 at 23:38, adult in rocky hill, $23^{\circ} 10^{\prime} 50.61^{\prime \prime} \mathrm{S} / 44^{\circ} 18^{\prime} 41.43^{\prime}$ W) On $05 / 04 / 14$ at 22:00, adult in rocky hill, $23^{\circ} 10^{\prime} 56.56^{\prime \prime} \mathrm{S} / 44^{\circ} 18^{\prime} 46.98^{\prime \prime} \mathrm{W}$ ) On 07/04/14 at 19:50 two adults in restinga area, $23^{\circ} 10^{\prime} 47.29^{\prime}$ S S/44¹8’37.89”'W]. 